\title{
Causes Of In-Migration To The Chainpur Bazar, Sankhuwa Sava District, NePal
}

\author{
Anup Shrestha \\ Reader, Mahendra Ratna Campus, Tahachal, T.U. Nepal
}

\begin{abstract}
Migration is the social and spatial movement of human population. This study has been confined to the identification of the causes of in-migration and its impact on the people of Chainpur Bazar of Sankhuwa Sava district. The study is based on primary data collected through field survey and focused group discussion. Altogether 67 household units were sampled for data collection. The study found that more women and children were involved in-migration and the major cause of migration was for getting quality education opportunity for the children.
\end{abstract}

Key Words: In-migration, livelihood opportunity, place of origin, education

\section{INTRODUCTION}

Migration is defined as the movement of people involving the change of geographical place from usual residence. Migration refers to the movement of human beings in the process of abandoning their original home land for same new destination across the boundary of the community or a country (Shrestha, 1983:1). In another word, a change in the location of residence is termed a spatial mobility. This mobility may be internal or international or local. The last one which involves a movement within a settlement is simply a residential relocation. According to the UN multilingual demographic dictionary "Migration is a form of geographical mobility or spatial mobility from one geographical unit to another, generally involving a change in residence from the place of origin or place of departure to the place of destination or place of arrival." (www.academia.edu/.../migration_and_ its_terminological)

Scholars working on migration have categories on various types and nature like internal and international migration as well as in migration and out migration. The nature of migration are also studies on seasonal cyclic, permanent-temporary voluntary, involuntary and another different way of rural to urban, urban to rural, rural to rural, city area to urban, urban to urban and geographical region like Hill to Tarai, Tarai to Hill etc. Migration also studies the flow, trend and patterns.

Migration is one of the major components of population change. Any change in the volume and flow of migration cause changes on the size, growth and other characteristic of the population both in sending and receiving area (KC 2003:121). It affects not only population size and composition but also in structure and characteristic. Migration is stated as completely socio-economic phenomenon which in the result of a complex mechanism involving social, psychological, economic, political institution and other determinants. Migration can make sudden ups and downs of the population size and its structure and distribution also. The study of migration is also of great importance and interest to demographers, economists, sociologists, policy makers, planners and other related scholars and administrators. This study is related with migration and education. Education is the most important factor of human life. It is often taken as the main factor of quality of life. Education determines the types of people living in the locality and their overall conditions. Different studies have indicated that educational attainments are vital indicators of migration of people from origin place to the destination. Migration is often analyzed as a response on "push and pull" factors and characterizing the zone of origin to destination place.

In the past agrarian society used to move to acquire better land due to high population pressure on cultivated land and such factors were used to cite as push factors, On the other the modern society have a movement for the greater opportunities for employment in the city, the better chance for the presence of facilities and services. The more varied social life, greater liberty of individual behavior and so on, have cited as pull factor. (UN 1956). The UN (1990) used more comprehensive definition about migrant worker that includes labor migration as a person who is to be engaged worker that includes 
labor migration as a person who is to be engaged or has been engaged in remunerated activity in a stated of which she or he is not a nation. Labor migration may have enormous potential for countries at both ends of the migration spectrum. For countries origin in addition to the possibility of providing some relief form unemployment and absorbing an increase in the labor force. It can provide a form of development support especially through remittance, transform of knowledge and certain of business and trend network.

This study has been focused on the situation of under employment, poverty and lack of facilities and services in the origin area and there is a better opportunities in the destination. By considering these various facets of population migration the present study has been attempted to analyze migration for better education in the Chainpur Bazar of Sankhuwa Sava District of Nepal

\section{MIGRATION IN NEPAL}

The history of migration has been a continuous process in Nepal. The internal migration has frequently changed the map of population distribution. Before the unification of the country migration was extremely limited; diversified small principalities were the main barrier of the migration. The conquest of the Kathmandu valley in 1769 marked the important chapter in the history of internal migration in the country (Kansakar 1974). In the recent years the national statistics present the overall absentees of the population from their origin is 1,921,494 in 2011 and it was only 762,181 in 2001 (CBS, 2012). Within a decade the defference of absentee population was over a million and the reason was to the aboard labor migration.

Inter-regional migration of population has been a notable phenomenon in Nepal. After the successful program lunching of malaria eradication and land re-distribution and settlement program, Tarai was the major destination place of population from hill side (CBS 2004: 55). The 1961 to 2001AD census reported that $3.37 \%, 4.4 \%, 2.61 \%, 3.44 \%$ and $3.24 \%$ people migrated within the national boundary respectively in each census (Kansakar 2003:108). The census report shows that the hill region was the main place of origin and the Tarai was the main recipient. Beside the migration from the Hill to the Taari, the stream is now from rural to urban and it is becoming a notable aspect in the case of Nepal.

In the present days, majority of people were involving in either due to unfavorable environmental condition in the place of origin or better opportunities in the place of destination. Migration has been taken as one of the most important ways by which people attempt to improve their living standard. It seems that mostly rural people are attracted by the bright light of the city. Nowadays large amount of young people are moving out of the country for the sake of better education and employment. Especially labor migration created a new phenomenon on the migration. Remittance of the foreign employment elevates the peoples' expectation and their lifestyle. Many people for better education of their child have been given priority and as a consequence they have been shifting to nearest and accessible urban and small town.

\section{FIG. I \\ LOCATION MAP OF STUDY AREA}

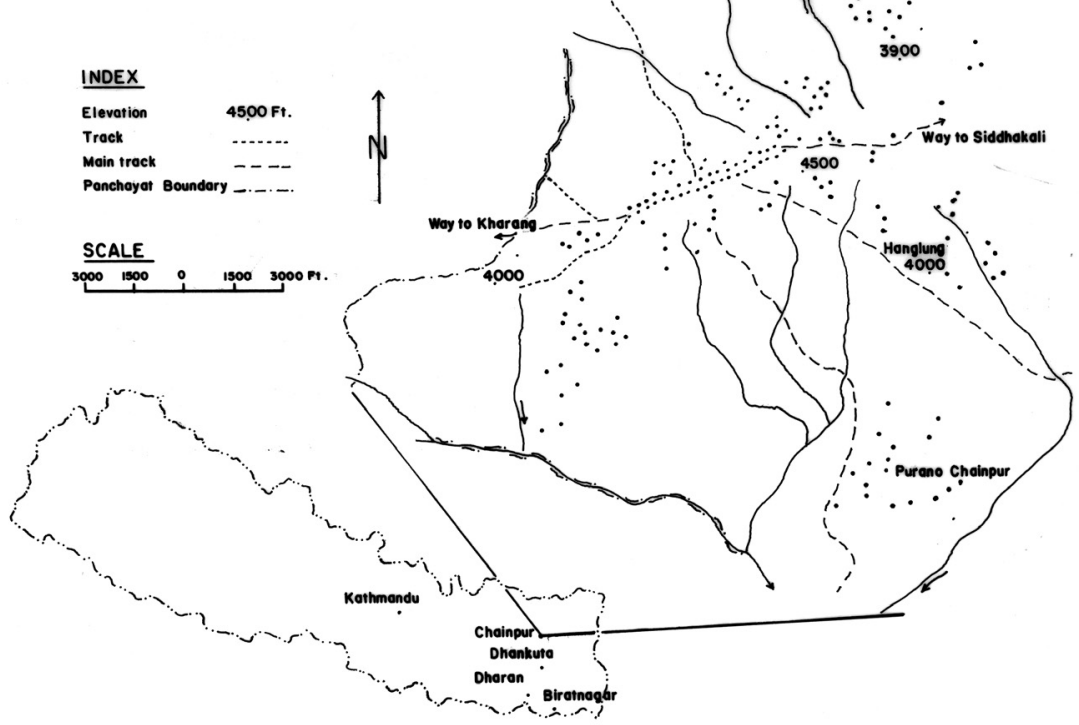




\section{THE STUDY AREA}

The study area is confined within the Chainpur Bazar and is located in the southern part of Sankhuwa Sava district of Nepal. The market center is located between $87^{\circ}-22^{\prime \prime}$ East longitude and $27^{\circ}$ 26" North latitude and about 206 kilometers east from Kathmandu and 90 kilometer north from Biratnagar. This was an important market center of the eastern hill region after the Nepal Tibet trade being conducted through Olangchunggola. But, when the district headquarter had been shifted from Chainpur to Khandbari because of its flat terrain located nearby the Tumlingtar Valley close to the Arun River in 1968 then after the relative importance of Chainpur has been declining. But in the course of time the Bazar is gradually gaining its importance with new development and motor road connectivity with Dhankuta, Dharan and many other small market centers of Terhathum and Shankhuwa Sava district itself. Because of these factors movement of people living in the peripheral rural areas are now coming and resettled over there (Figure 1).

\section{METHODS OF DATA COLLECTION}

The data collection procedure was followed by house hold survey and basic information was collected form key informants including school teacher, VDC secretary, community and local leaders. An open discussion was conducted to get the basic information of the area as well as the in-migrant families inhabited in the Bazar area. Following that discussion, a list of in-migrants was prepared with their help. After the preparation of the list systematic random sampling was used to select the informants from migrants, list. Altogether, 67 families were sampled. Each sampled household was visited for the data collection with structured questionnaire. Besides the household information, the general trend and causes of migration was compiled through the focus group discussion.

\section{DEMOGRAPHIC CHARACTERISTICS OF THE RESPONDENTS}

The demographic characteristics of the surveyed population is given in table 1 . It shows that $73.13 \%$ of the female respondents were belongs to age group of 31 40 when male being only $5.97 \%$. The age group of $20-30$ and $41-50$ were $10.45 \%$ and $7.46 \%$. Age group of $20-30$ consists of $10.45 \%$ of female whereas $41-50$ is $2.99 \%$ of male and $7.46 \%$ of female. It can be seen that the highest respondent i.e. $79.13 \%$ was the age group between $31-40$ years.
Table 1: Demographic characteristic of respondents.

\begin{tabular}{|c|c|c|c|c|c|c|}
\hline \multirow{3}{*}{$\begin{array}{l}\text { Age } \\
\text { group }\end{array}$} & \multicolumn{4}{|c|}{ Sex } & \multicolumn{2}{|c|}{ Total } \\
\hline & \multicolumn{2}{|c|}{ Male } & \multicolumn{2}{|c|}{ Female } & \multirow{2}{*}{ No. } & \multirow{2}{*}{$\%$} \\
\hline & No. & $\%$ & No. & $\%$ & & \\
\hline $20-30$ & - & - & 7 & 10.45 & 7 & 10.45 \\
\hline $31-40$ & 4 & 5.97 & 49 & 73.13 & 53 & 79.13 \\
\hline $41-50$ & 2 & 2.99 & 5 & 7.46 & 7 & 10.45 \\
\hline Total & 6 & 8.96 & 61 & 91.04 & 67 & 100 \\
\hline
\end{tabular}

Source: Field survey 2012

Table 2 demonstrates about the age and sex composition of migrants in study area. Highest percentage of $51.85 \%$ of the migrants belongs to the age group of below 15, i.e. $33.33 \%$ being male and $18.15 \%$ were female. Age group of $15-45$ consists of $42.33 \% ; 8.47 \%$ and $33.86 \%$ male and female respectively. On the contrary, only $5.82 \%$ of the migrants belong to the age group of 45 and above, with $1.05 \%$ male and $4.76 \%$ were female.

Table 2: Age and sex composition of migrants

\begin{tabular}{|c|c|c|c|c|c|c|}
\hline \multirow{2}{*}{$\begin{array}{c}\text { Age } \\
\text { group }\end{array}$} & \multicolumn{2}{|c|}{ Male } & \multicolumn{2}{c|}{ Female } & \multicolumn{2}{c|}{ Total } \\
\cline { 2 - 7 } & \begin{tabular}{c} 
Num- \\
ber \\
\cline { 2 - 7 }
\end{tabular} & $\%$ & $\begin{array}{c}\text { Num- } \\
\text { ber }\end{array}$ & $\%$ & & \\
\hline below 15 & 63 & 33.33 & 35 & 18.15 & 98 & 51.85 \\
\hline $15-45$ & 16 & 8.47 & 64 & 33.86 & 80 & 42.33 \\
\hline 45 above & 2 & 1.05 & 9 & 4.76 & 11 & 5.82 \\
\hline Total & 81 & 42.86 & 108 & 57.14 & 189 & 100 \\
\hline
\end{tabular}

Source: Field survey 2012

Moreover out of total $42.86 \%$ of the migrants were male and $57.14 \%$ were female. Female population has been leading the trend of the migration in this study area than the male population. 


\section{CAUSES OF IN MIGRATION}

Table 3 shows the response to the reason of migration. It can be seen from that, more than half $(56.27 \%)$ of the respondents migrated for their better education. Similarly, $19.42 \%$ were migrated for seeking the better job opportunity.

Table 3: Causes of migration

\begin{tabular}{|l|c|c|}
\hline \multicolumn{1}{|c|}{ Cause } & Number & Percentage \\
\hline Better education & 38 & 56.72 \\
\hline Job transfer & 4 & 5.97 \\
\hline Job opportunity & 13 & 19.40 \\
\hline Easy life & 7 & 10.45 \\
\hline Security/conflict & 5 & 10.46 \\
\hline Total & 67 & 100 \\
\hline
\end{tabular}

Source: Field survey 2012

Likewise, for easy life and security or conflict became the reason of migration for $10.45 \%$ and $10.46 \%$ respondents respectively and $5.97 \%$ of respondents

\section{Outcome of the FGD}

श्रीमान बैदेशिक रोजगारमा छन्, बच्चालाई राम्रोसँग पढाउनु पई भन्ने सल्लाह भएर आएको ।

"Husband has gone for foreign employment; we decoded to provide better education to our children."

गाउँमा राम्रो स्कुल छैन, केटाकेटी पढाउन पनि आउँनै पय्यो नी।

"Village lacks better quality school so had to come here for the sake of children's education"

केटाकेटीले राम्रो पढ़्न पाउँछन र गाउँमा जस्तो दुख गर्नु पर्दैन, सुख सुविधा धेरै छ।

"Children can attain school; also life is much easier here because of different facilities"

बिदेशको कमाई आउने भएकोले केटाकेटीलाई पढाउन पाईने अनि त्यसबेला गाउँमा माओबादी दून्दले बस्नपनि गाह्र भयो ।

"Income from foreign remittance made us able to provide education to children. Maoist insurgent at that time made it tough to sustain our life in village". were migrated because of their job transformation. Since, most of the respondent migrated for the better educational facility; in consequence there is a large number of age group of below 15 years of age and 15 to 45 of age as their guardians.

Following the identification of causes of migration, focus group discussion (FGD) was conducted and the response was cited accordingly.

Those points of the group discussion lead to different reasons for the migration. Lack of education and security in the village became the push factors for the migrants. They were fascinated by the better chance of education in the city area. Facility of proper education for children can be pointed as the major reason for migration as mentioned by the migrants. In search of better education for their children they had to leave their previous place. Increase in the living standard also encouraged them to migrate. In the case of this study migration can be describe as a consequence of labor migration (foreign employment).

\section{CHANCE OF RETURN MIGRATION}

The chance of participating migrants returning to their place of origin seems to be null as they have left their place for the better life standard, they planned to settle there. Most of the migrants don't want to return back again whereas, some migrants were still in confusion if they want to go back or settle there. They were not confident and answered.

\section{Outcome of the FGD}

अब गाउमा फर्कन त गाहै होला बरू गाउको घर वेचेर यतै बन्द ब्यापार तिर पो लाग्नु पछ होला।

Now its hard to return back to village, rather thinking to sell property in village and be involve in business.

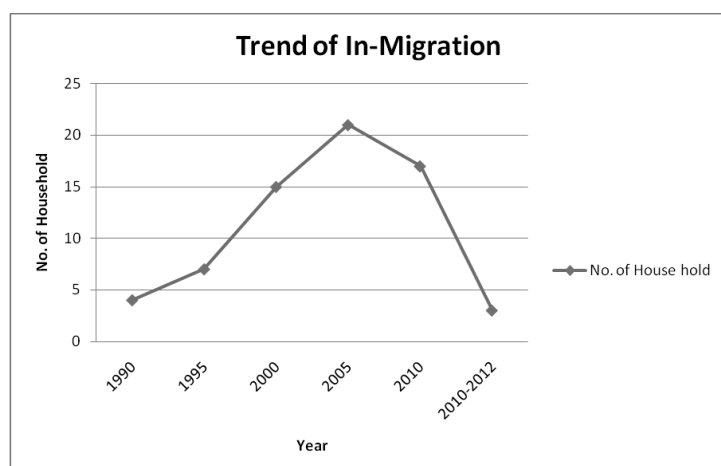

Figure 2 
Table 4: Trend of in-migration

\begin{tabular}{|l|c|c|}
\hline \multicolumn{1}{|c|}{ Year } & No. of Household & $\%$ \\
\hline 1990 & 4 & 5.97 \\
\hline 1995 & 7 & 10.45 \\
\hline 2000 & 15 & 22.39 \\
\hline 2005 & 21 & 31.34 \\
\hline 2010 & 17 & 25.37 \\
\hline $2010-12$ & 3 & 4.48 \\
\hline Total & 67 & 100 \\
\hline
\end{tabular}

Source: Field survey 2012

Table 4 and Figure 2 demonstrate that the changing trend of in-migration starting from 1990 to 2012. The table indicates that before the $1990 \mathrm{AD}$ the trend of migration was only $5.97 \%$, This trend starts with the negligible number. However, after 1990 this trend started to rise up $10.45 \%$ to $22.39 \%$ during 2000 . In 2005, this trend elevated up to $31.34 \%$ marking the highest period of migration till 2012. After 2010 to 2012 migrations lessened by almost three times in compare to previous records. In 2010-2012 the trend of migration is dropped to $4.48 \%$. This data indicates that the maximum number of migration has been flowing during the 2000 to 2005, which was also the period of Maoist insurgent. So, from this it can be concluded that if the migrants mentioned different reasons, it could linked to the period of Maoist insurgent.

\section{CONCLUSION}

This study indicates that most of the migrants are children and women. They had migrated for the better education of their children and employment was taken as the second reason. Remittance became the push factor. As they earn money from overseas it encouraged them to afford the better facility of education. Migrants were spending more money for their children's education than non-migrants people. Majority of the people are spending their remittance for better education of their children. Maximum number of migrants during the period of Maoist insurgent indirectly suggests the hidden cause of migration; they might have migrated to city in search of security. Concepts of better life with availability of different facilities lead most of the people to migrate from their place of origin to city or developed areas. Idea of teaching their children in English medium school or Boarding Schools enforced most of the parents to make a decision of migration. Better food and clothing options with less physical work fascinated the migrants. Also the easy availability of health, communication and transportation facilities became the supporting pull factors.

\section{REFERENCES}

CBS, 2012. Rastriya Janaganana 2068 Samkshipta Natija (National Population Census 2011 and its preliminary result). Kathmandu: Central Bureau of Statistics, Government of Nepal,

CBS, 2004 Nepal National Population Report 2001, Kathmandu: Central Bureau of Statistics, Government of Nepal

Kansakar V.B.S. 2003. Internal migration and citizenship in Nepal, In Population Monograph of Nepal vol. II Central Bureau of Statistics, Kathmandu.

Kansakar, V.B.S. 1973-74 History of population migration in Nepal. The Himalayan Review, Vol. VI, No. $5 \& 6$.

KC, B. K. 2003. Internal migration in Nepal. In Population Monographs of Nepal vol. II Kathmandu: Central Bureau of Statistics, Government of Nepal

Shrestha, C.B. 1983:1 Ridge to Valley Migration of Population in Nepal; A case study of the Chackkhola Area. Kathmandu CEDA (Center for Economic Development and Administration)

www.academia.edu/.../migration_and_its_terminological 